Jose Albors-Garrigos ${ }^{1}$, Antonio Collado²

'Universitat Politecnica de Valencia, 46022 Valencia, Spain

${ }^{2}$ Ford España S. L. - Polígono Industrial, 46440 Almusafes, Valencia, Spain

\title{
Success and Threats in the Clustering of the Automotive Industry in Spain: The Role of Public and Private Agents.
}

DOI: 10.7595/management.fon.2019.0002

\begin{abstract}
:
Research Question: This article clarifies the role of clusters in industry agglomeration efficiency as well as the role that public and private agents play in their efficiency. Motivation: The automobile industry in Spain is an exception to the industrial decline suffered by the secondary sector since the economic crisis exploded in Spain. Employment in the vehicle manufacturing industry has recovered significantly in Spain in 2017, with a significant growth bringing it closer to 2008 levels. The sector accounts for $8.6 \%$ of the country's GNP. How can we explain this success? Are there new threats (technology, environmental standards, emerging economies, etc.) menacing the sector? Based on value chain and cluster theories we explain its success and how new threats could be managed? The response lays in analyzing the role of cluster agents in the various clusters dynamics. The research shows how the openness of clusters plays a crucial role in their sustainability. Idea: Based on value chain and cluster theories we explain their success and how new threats could be managed? The response lays in analyzing the role of cluster agents in the various clusters dynamics. The research shows how the openness of clusters plays a crucial role in their sustainability. Data: primary data was collected in two surveys and interviews campaigns during 2013 and 2017. Furthermore, secondary data from national, regional and sectoral sources were analysed. Tools: The research is based on a series of interviews and visits to the automotive clusters in Spain. Additionally, the authors have analyzed abundant secondary information and web contents available on the clusters agents: manufacturers, suppliers, unions, associations, etc. Findings: The paper concludes that regional and national policies are relevant but that consensus between clusters' agents is essential for their success. However, will the existing agents be able to withstand new threats? .Contribution: The article contributes to clusters literature and the clusters' role of the agents in the global value chain context. It also sheds light on public policies to support automotive industries. Limitations are linked to resource limitations.
\end{abstract}

Keywords: automotive industry, clusters, cluster agents, global value chain, industry public policies.

JEL Classification: L52, L62

\section{Introduction}

It is interesting to note that Spain has become the leading producer of commercial vehicles and the second largest car manufacturer in the European Union as well as the 12th largest in the world. In 2017, the number of vehicles manufactured in Spain exceeded 2.8 million. Also, the automobile and components sector has a commercial coverage abroad of $150 \%$. The industry accounts for $17.6 \%$ of Spanish exports, $8.6 \%$ of 
GNP and 9.6\% of employment in 2017 (ANFAC (2018;). This development has taken place in spite of the 2008-09 economic crisis that affected the automotive industry in Europe as well (Sturgeon \& Van Biesebroeck, 2010; Pavlinek, 2015).

How can this situation be explained when we have not had a Spanish car manufacturer with its technology for many years? This circumstance must be considered in spite of argumented theoretical shortcomings about the European automotive industry (Laux, 1992, p.13; Welfens, 2014, p.53). The first reason is that the group of actors in this sector have been acting together for a long time, which has allowed them to develop strategies and promote policies that have been able to convince the various governments adequately, which has forced them to implement very active industrial policies, unlike in other similar sectors. This fact has proved to be a powerful magnet for attracting the attention of foreign multinational companies that have found Spain to be an exciting place to practice their industrial actvity. It must be stressed as well that at the time this article was written a number of global threats were menacing the industry situation.

But within these factors, the role that clusters play in this industry cannot be forgotten. Two seminal publications (Sturgeon and Lester, 2004; Sturgeon, Van Biesenroeck \& Gereffi, 2008) point to how the automotive industry was configured globally following a series of guidelines within which a wave of offshore investments, mergers, alliances, and acquisitions were fundamental, especially in the 1990s. These developments have contributed to the present value chains configuration, within a strong current of globalization, made up of large companies that are firmly related to each other at a global level and where delocalization has played a fundamental role in achieving flexibility. Leading large enterprises have exercised strong governance in their global value chains and have influenced this current of offshoring (Sturgeon, Van Biesebroeck, \& Gereffi, 2008; Sturgeon \& Van Biesebroeck, 2010; Rutherford \& Holmes, 2008). In this direction, particular attention has been paid in the academic literature to the situation and context in emerging countries (Evren \& Sakarya, 2017; Taura \& Watkins, 2014; Dibben et al., 2016).

There is also a particular strain between the subcontracting or not subcontracting of value-added activities such as design and R\&D between car assemblers (OEM "Original Equipment Manufacturers," from now on) and others, with trends towards modularity playing a fundamental role (Laseter \& Ramdas, 2002; Bierau et al., 2016). The analysis of the latter gives a significant role to regional and national structures that appear to support the coherence of the industry. This situation explains why economic geography plays a different role depending on the segments of the value chain: design, component manufacturing, assembly, etc. In this context, at the micro level, regional clusters are fundamental and, in Spain, they have developed providing critical competitive advantages that have favoured the development of the industry at the national level (Schulze, MacDuffie\&Täube, 2015; Bierau et al., 2016).

\section{Theoretical Context}

The clusters we are dealing with here would respond to Porter's (2000) classical viewpoint. The governance of global automotive value chains plays an essential role in shaping these regional agglomerations. More recent approaches applied mainly in the automotive industry, where spatial and virtual proximity play significant roles (Brenner, 2017). However, recent competitive movements among main OEM players question the part of emerging countries' agglomeration challenging their advantages (Dibben et al., 2016).

The school of the Value Chain theory (Gereffi, Humphrey, \& Sturgeon, 2005; Gereffi \& Fernandez-Stark, 2016) proposes that the tension between centralization of assembly and fragmentation of production is coordinated through governance of global value chains (GVC). The GVC literature identifies a typology of five governance structures: markets, modular, relational, captive, and hierarchy. These compositions are measured and determined by three variables: the complexity of the information shared between actors in the chain; how the knowledge for production can be codified; and the level of supplier competence (Gereffi et al., 2005; Gereffi \& Fernandez-Stark, 2016). The degree of coordination regulated by the power asymmetry between actors (OEM vs. Suppliers) will depend on various factors as noted in the attached table (Nyaga et al., 2013). It can be observed that in the automobile industry, situations often occur that vary from modular to hierarchical governance, depending primarily on the capacity of the suppliers and the hierarchical orientation of the OEM depending on the transactions, complexity, the coordination, and power symmetry (Gereffi et al.,2005).

Some regions may present a different governance profile from others depending on the leadership exercised by the OEM (Plum \& Hassink, 2013; Hassink, Plum, \& Rickmers, 2014). Other actors play important roles as well in the governance profile of the value chain. 
Within this context, one of GVC and automotive clusters, this paper will analyze the roles that cluster agents: OEM manufacturing companies, component suppliers, institutions, associations, universities, central and regional governments, and public research bodies, etc. have played in the configuration of clusters. The cluster environment facilitates the quality of interaction between value chain actors, thus leading to the responsive value chain paradigm. This paradigm has been defined as a network of companies able to create wealth to all their components in a competitive context by reacting quickly and effectively in costs and technology to changes and market demands. (Gunasekarana, 2008; Lau \& Lee, 2000). This paradigm is valuable when it comes to explaining the advantages of cooperation between actors in the chain, the cluster, and the industry leaders. The quality of the links between the various actors in the cluster also shapes their development and orientation according to our field study.

But which are the critical elements that compose this relationship? According to Oh and Rhee (2010) and Dyer and Chu (2003), they could be summarized as follows. On the side of the supplier: modularity, flexibility, and engineering skills, as well as an effective cost management. On the other hand, there are the relationships between the supplier and the customer demand that could be due to five dimensions: personal contact, the permanence of the relationship, supplier selection routines, support of supplier development and a process of new product development.

The advantages for the OEM would be a reduction in costs and time, reduction in changes and re-engineering, information and reduction of uncertainty, continuous improvement, solving design and process problems, as well as strategic alignment.

Knowledge is a valuable asset to be taken into account when we consider the activities of the OEMs in their areas of influence. Two basic configurations of knowledge have been proposed: analytical and synthetic; the former, mainly related to R\&D; the latter synthetic, primarily related to engineering and design. Thus, these activities ultimately influence the value-added tasks of the other components or agents of the cluster: Tier 1 and others. Unfortunately, automotive companies rely heavily on the latter, the synthetic knowledge base while their analytical knowledge base is rather weak and this affects their innovative capacities (Plum \& Hassink, 2013).

This knowledge interexchange contributes to OEM coping with the turmoil caused by globalization, new governmental regulations, and advances in new technologies (Pérez \& Sanchez, 2002; Schulze, Mac Duffie, \& Täube, 2015). Additionally, the OEM competition and cooperation dynamics affect the automotive agglomerations, and their mutual influence as the new examples of acquisitions show, in particular in the Spanish case, as it will be examined later (Akpina r\& Vincze, 2016).

Eisingerich et al. (2010) have proposed a model to analyze the sustainable performance of a cluster. We can define this performance by specific measures recognized by the academia, i.e., the rates of technology transfer local employment share and the growth, regional percentage of GNP, and production growth (Spencer et al., 2010).

This model considers three essential factors:

(a) the strength of the networks that support it considering the trust between its members, the frequency, and intensity of exchanges as well as the duration of the relationship, also pointed out by Welfens (2014) in the case of the automotive industry;

(b) The openness of its networks and their diversity, which facilitates cluster members access to new knowledge and skills. It is a function of network membership diversity, willingness to accept new members, and the extent to which there are ties to organizations outside the cluster;

(c) The uncertainty of the environment. This factor, according to Eisingerich et al. (2010) has a moderating effect on the former. The uncertainty is a function of market turbulence, the intensity of competition, and the technological changes. The latest news related to the new European regulation changes, ownership evolution, increasing competition of emerging African industry, European de-investment of certain American brands are clear examples of these uncertainties. Technology threats and opportunities have been cited as one of the most potential radical changes in the automotive industry which are requiring road mapping exercises from OEMs and suppliers (Förster, (2015).

This model considers that both network openness and strength are contingent with the network uncertainty. The positive effects of network openness are likely to increase as environmental uncertainty increases, while the positive impact of network strength on cluster performance tends to decrease as environmental uncertainty increases. Moreover, similar approaches have recently been proposed in the automotive industry in emerging countries (Nedelcu, 2015; Bhaskaran, 2014). 
Thus, in the model shown in figure 1, we can summarise the commented paradigms that relate the essential elements to consider in the sustainability of clusters as those that concern us and that constitute the basis of our analysis.

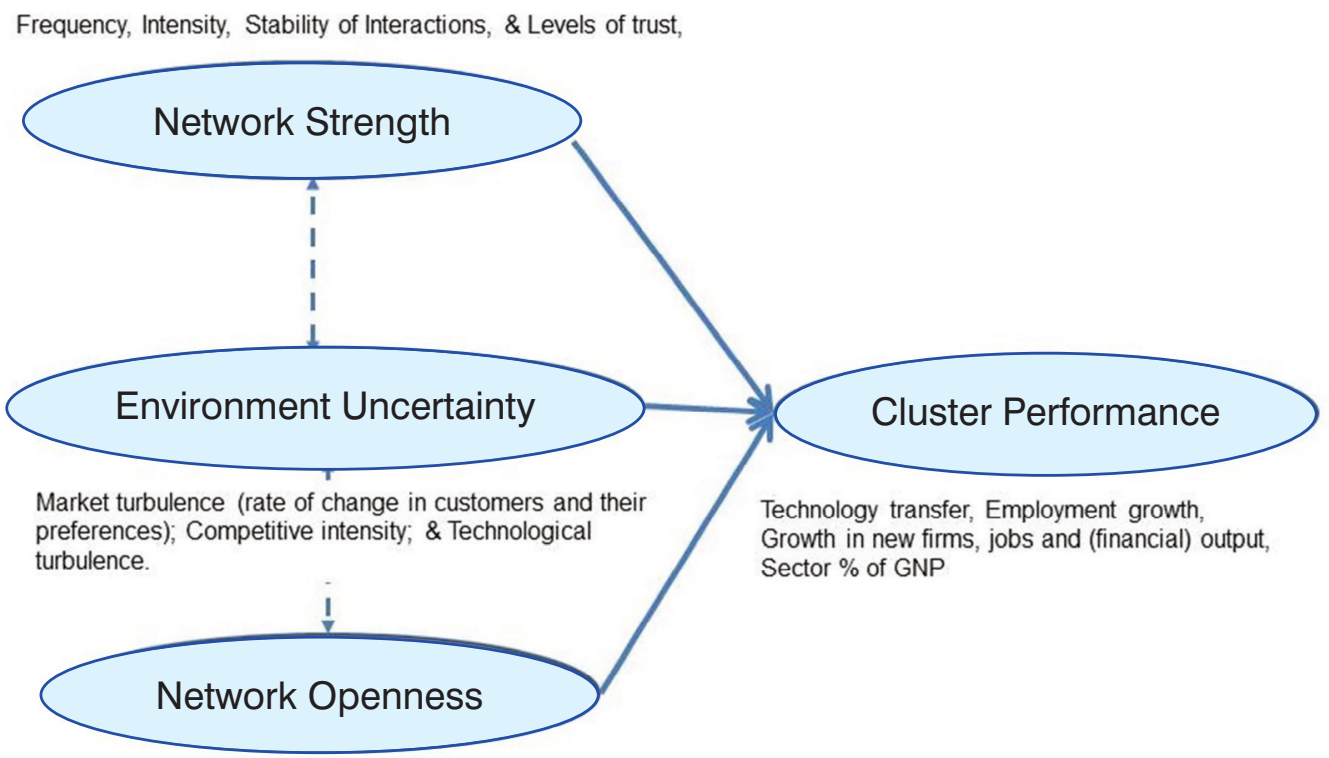

Network membership diversity, Willingness to accept new members, \& Ties to Organizations Outside the Cluster

Figure 1: Essential elements required for the cluster sustainability (authors based in Eisingerich et al 2010).

We can conclude that there is a stream of thought in the academic literature that has analyzed clusters and, specifically, automotive clusters concerning the factors that impact their performance. However, there is limited literature analyzing the relevance of the various actors in this process. This field is the research gap that this article tries to fill.

\section{The Context. The Automotive Industry in Spain. Geographic Agglomerations.}

Since the introduction of the various vehicle manufacturers in the 1960s, the industry has been grouped around the geographical areas of influence of these locations. Thus, if we consider the geographic distribution of industrial activity centres in the automotive sector, Table 1shows the weight of industries with more than 200 employees, employment in the industry, the number of suppliers, car manufacturers (OEMs) and the percentage of turnover over the national total in each region. It can be observed that these agglomerations are mostly concentrated around the leading car manufacturers in Spain and that these regions have formally formed cluster-type industrial associations. Subsequently, we will analyze the weight and dynamism that these organizations have implied in each area. 
Table 1: Socioeconomic influence of the Spanish automotive industry according to clusters distribution (ANFAC 2018).

\begin{tabular}{|c|c|c|c|c|c|c|c|}
\hline $\begin{array}{l}\text { 음 } \\
\text { व్ }\end{array}$ & 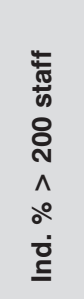 & 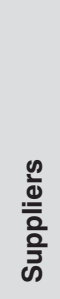 & 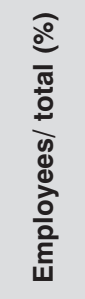 & $\sum_{\text {U }}^{\infty}$ & 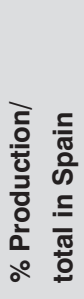 & 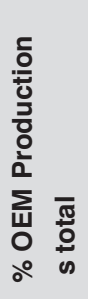 & 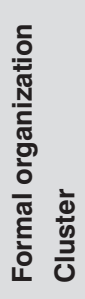 \\
\hline Cataluña & 27.60 & 393 & 34.30 & $\begin{array}{l}\text { Seat, IVECO, } \\
\text { Nissan, Daimler }\end{array}$ & 23.73 & 19.24 & $\mathrm{x}$ \\
\hline Galicia & 14.30 & 64 & 7.70 & PSA. Citroen & 15.77 & 15.27 & $x$ \\
\hline Aragon & 10.50 & 109 & 7.70 & GM & 13.3 & 13.43 & $\mathrm{x}$ \\
\hline $\begin{array}{l}\text { Castilla } \\
\text { Leon }\end{array}$ & 9.50 & 61 & 7.80 & $\begin{array}{c}\text { Renault, IVECO, } \\
\text { Nissan }\end{array}$ & 15.73 & 20.36 & $x$ \\
\hline Navarra & 9.50 & 81 & 7.60 & VW & 12.73 & 8.37 & $x$ \\
\hline País Vasco & 7.60 & 131 & 11.00 & Daimler, Irizar & 3.34 & 5.28 & $\mathrm{x}$ \\
\hline Valencia & 6.70 & 83 & 7.50 & Ford & 11.76 & 14.64 & $x$ \\
\hline Madrid & 4.80 & 125 & 4.80 & $\begin{array}{l}\text { PSA, Renault, } \\
\text { IVECO }\end{array}$ & 3.64 & 3.22 & $x$ \\
\hline Cantabria & 3.80 & 10 & 3.00 & no & & & $x$ \\
\hline Andalucía & 1.90 & 65 & 3.60 & Renault & & 0.20 & \\
\hline Rioja & 1.90 & 17 & 1.60 & no & & & $x$ \\
\hline Asturias & 1.00 & & 0.60 & no & & & \\
\hline $\begin{array}{l}\text { Castilla la } \\
\text { Mancha }\end{array}$ & 0.90 & 29 & 1.30 & & & & \\
\hline Other & 0.00 & & 1.50 & & & & \\
\hline Total & 100 & & 100. & & 100 & 100 & \\
\hline
\end{tabular}

\subsection{Main agents in the clusters.}

Morosini (2004) postulates that the structure of economic and social agents in the cluster is what binds the cluster's network and serves as the "institutional and virtual glue" of the agglomeration. Therefore, this same author identifies five necessary skills in the cluster to develop a competitive dynamism: leadership, a stock of knowledge that constitutes the building blocks of its structure, communication rituals, interactions of knowledge exchange and the rotation of professionals within it. Other authors have recognized the role of agents in structuring the cluster's knowledge architecture (Sureephong et al., 2007). These authors coincide with Plum and Hassink (2013) in their study of German car clusters where they assigned an essential role to knowledge generation.

These agents, in the specific case of automotive and truck clusters, would be the following.

Manufacturers of automobiles (Original Equipment Manufacturers or OEMs of cars and trucks, ANFAC) or (OEMs of Buses (ASCABUS). This is how significant the number of them is, their seniority over time, the participation, commitment or role they acquire in the cluster, their policy of selection and support of suppliers in which decision-making may be vital if it is local or centred in the multinational's headquarters and, finally, if they have value-added activities such as R\&D or design in the area.

Here we must stress the percentage of production volume of these segments for 2017. As Table 2 shows, the automotive segment (including light vans) amounts to almost $98 \%$ of the total sector. However, the statistics discussed in this article frequently refers to the totality of the industry. 
Table 2: Production volume of various automotive segments in Spain for 2017.

(ANFAC and ASCABUS, 2018).

\begin{tabular}{|l|r|l|}
\hline National production & Units & $\%$ \\
\hline Automobiles & $2,585,182$ & 89.93 \\
\hline Light vans & 221,162 & 7.69 \\
\hline Trucks & 64,566 & 2.25 \\
\hline Buses & 3,680 & 0.13 \\
\hline
\end{tabular}

Component manufacturers. They make up the value chain upstream and downstream of manufacturers (OEMs). According to their proximity to these they are called Tier 1, 2, 3, etc. They have a fundamental role and their number, dimension, and level of internationalization are a symptom of the dynamism of the cluster where they have developed. It should be noted that the existence of a secure network of component manufacturers is one of the elements that have contributed to the health of the national automotive industry (Sturgeon et al., 2008).

Cluster Associations. Academic literature is scarce regarding this type of agents; some authors call them Cluster Development Agencies (Sureephong et al., 2007). This is a kind of partnership with a dynamic role. It may have been promoted by management, an OEM or other regional associations. A recent study (Beldarrain \& Clemente, 2011) analyses how the various offices in Spain work carrying out communication, purchasing, projects, etc. Although they rely on public financing, the percentage of private funding is a symptom of their dynamism.

Universities. Universities are knowledge-generating agents with a specific role in the cluster in which they are integrated. They can collaborate in generating analytical and synthetic knowledge in the cluster. Also, they can be training agents for the local industry. There are success stories in Europe such as Slovakia, Gratz, Bavaria or Canada (Rutherford and Holmes, 2008). Other authors have outlined this role in emerging countries (Cabelkova, Normann \& Pinheiro, 2017).

R\&D Centres, Technological Institutes. Some clusters have private or public centres, as well as technological institutes specializing in the automobile industry, which contributes to the knowledge of the automobile industry. Some of them are a consequence of the cluster's activity (Cabelkova, Normann \& Pinheiro, 2017; Morosini, 2004).

Labour Unions. They have been ignored by academic cluster literature. They collaborate on advanced legislation and collective bargaining. A good working environment and cluster-level cooperation will be hampered by overcapacity and the reduction of costs that reverberate across global value chains (Rutherford \& Holmes, 2007). Two levels should be considered. First of all, the multinationals (OEMs), assemblers and the large national and multinational Tier 1 component manufacturers, where there is a flexible and agile communication between unions and management with well-articulated labor relations. Secondly, the SMEs, in the auxiliary industry, where union membership is lower. Some authors point to shifting cost cuts down the chain, as we move in that direction with lower value-added jobs and more impoverished working conditions (Banyuls \& Lorente Campos, 2010).

Local Government and Administration.

Regional governments are contributing to supporting industry and local clusters. With a greater or lesser prominence, they have promoted cluster offices and regional support policies. There are numerous programmes to help this clustering in the sector. However, industrial policy is somewhat reactive to the proposals of employers.

National Industry Associations. The Spanish COMPONENTS manufacturers association (SERNAUTO), The Spanish national automotive and Truck manufacturers association (ANFAC) or regional associations such as chambers of commerce or cooperation institutes are critical to cluster dynamics. 


\section{Methodology of Research. Field Study}

\subsection{Information sources.}

This work is based on the collection of secondary information from multiple sources: academic publications, business publications, websites of the various clusters and business associations, statistics, etc. Additionally, and as primary sources, information was obtained from more than 50 interviews with managers of multiple clusters as well as component manufacturers and heads of the Ministry of Industry. Moreover,50 questionnaires were collected directly from cluster agents in the various clusters.

\subsection{Questionnaires and interviews.}

The aim was collecting ratings for the various variables of the proposed model. Primary and secondary information was standardized and transformed in Likert scale variables.

The Network Strength is composed of four dimensions: components and OEM relationships in the line of the responsive Value Chain paradigm, the OEM leadership, the union coherence with the cluster goals, and the and coordination of the Cluster. These variables are graded through the questionnaire responses, based on a Likert scale.

The Network openness was composed of four factors: network membership diversity which implies the existence of a variety of agents including all those involved in the automotive value chain, willingness to accept new members, and the extent to which there are ties to organizations outside the cluster. We have selected four proxies for these variables: (a) whether the cluster has agents covering all aspects of the value chain (OEMS, components, R\&D agents, governance, training or ties with associations) and a certain excellence level; (b) whether there has been new members (agents) in the past five years; (c) members turnover growth in the same period, and (d) whether there are organized and permanent ties with other European networks. These variables have been measured with a mix of secondary and primary information (questions).

Environment Uncertainty has three components: Threats of OEM divestment; Environmental standard Threats and Technology Turbulence. The three variables are established on questions (again, Likert scale) in the survey.

Finally, Cluster performance was composed of three variables: Production growth \% Employment and \% region GNP. This was measured by analyzing the statistics of a five year period (2012-2017) and the standardized coefficients were applied a 1-5 scale.

\section{Discussion and Analysis.}

Next, we analyze the dynamics of the different agents in the various clusters from different perspectives according to the information collected.

Manufacturers of automobiles (OEMs), trucks or buses.

\section{Renault.}

Renault built its factory in Valladolid in 1951, and its plant in Palencia in 1978. It has an uncritical R\&D department. In Seville it manufactures gearboxes. It has a substantial involvement in the Castilla León cluster with four production plants. Its industrial plan contemplates an investment of 600 million euros between 2014 and 2016. It has recently announced an additional investment in Spain of 600 million euros and the development of an R\&D centre in Valladolid.

\section{PSA Citroen}

The Vigo (NorthWest of Spain) factory was built in 1958. It is the most productive factory of the multinational (14\% of PSA production) with the export of $85 \%$. It inaugurated a new modular platform in 2014 after investing 1,062 million euros in 2009-2013. It has an active involvement with CEAGA, the Vigo cluster. Its production in 2017 was 424,000 units. The recently signed partnership with GM will undoubtedly affect their operations in Spain due to the presence of Opel (GM Europe) in Zaragoza. 
The Madrid plant was inaugurated in 1952 by a famous Spanish entrepreneur, Eduardo Barreiros (GarcíaRuiz \& Santos-Redondo, 2002). In this plant vehicles were successively manufactured for Simca, Chrysler, Talbot, Peugeot, and Citroën. The PSA produces some models exclusively for the whole world. Actually, they produce the Citroen Cactus and a new model is foreseen for 2021. Its actual output was of 81,000 vehicles during 2017.

Due to the acquisition of General Motors by the PSA group, its role may be changing shortly.

\section{Ford}

Since its construction in 1976, this Valencia plant has been one of the most active in recent years. Since 2011 it has invested 2,300 million euros in expansion and improvements. Ford's purchasing policy does not favour the Valencia automotive components environment. It is, above all, a very flexible production plant; it does not try to lead a cluster. The firm has cooperation on a permanent basis with a local university. Recent problems with the European branch of Ford are threatening its immediate future.

\section{General Motors}

Opel's Figueruelas Plant (Zaragoza) has been operating since 1982. It accounts for $20 \%$ of GM's manufacturing workforce in Europe. Since its launch, Opel has invested more than 4.3 billion euros. In 2014, they invested more than 210 million euros. The recent acquisition merge between PSA Citroen and General Motors has affected recently the cluster situation where workers were forced to accept new salary restriction agreements given the potential production movements of the Opel Corsa model. Recently, the manager of the GM plant in Zaragoza made public their request of a $20 \%$ cost reduction to their suppliers to keep their competitiveness.

\section{Nissan}

Nissan built its Barcelona factory in 1971 which is also being threatened. It has Tier 1 and two suppliers located within its plant, which includes an R\&D centre in which 70 million euros are invested annually in R\&D. It built the Ávila factory in 1955 to produce industrial truck models. There, it has invested 430 million euros between 2014 and 2015.

\section{Volkswagen Audi}

The Landaben factory was started in 1965, first as Authi (Morris, MG, Mini,Austin and Victoria) and later as Seat. Since 1983, the Volkswagen Polo has been produced in Landaben, the Volkswagen factory in Navarre. Since the end of 2018, a second model with the same platform, the new small SUV, the Volkswagen T-Cross Audi uses the Martorell Seat plant in Barcelona to produce Audi with a capacity of 100,000 vehicles per year, and it has been planned to build the A1 from 2019 (ANFAC, 2017).

\section{Seat (second brand of Volkswagen)}

Seat was a Spanish brand licensee of Fiat. Later, in 1986, it was acquired by VW. The Martorell plant was built in 1993. Together with Audi, it is the most important the brand in the world, the only installation in Spain with an R\&D and design centre with 900 engineers and a prototype centre. This company has invested more than 2.6 billion euros in the last five years. It also has a production centre for stamped parts and another where it has been manufacturing gearboxes since 1980. Seat has played a relevant role in the Barcelona cluster evolution (Catalan, 2017). This firm has set an exportation record during the first quarter of 2018 with 139,200 cars sold, an increase of $18.7 \%$ on the previous year's figure.

\section{Daimler Mercedes}

They own a van factory in Vitoria, inaugurated in 1954. Through its subsidiary, Evo Buslbérica manufactures bus chassis in Cantabria. The company invested billions in the last five years.

\section{IVECO (former Fiat trucks)}

The Valladolid truck factory was inaugurated in 1957 and the firm has invested more than 105 million euros for the new light van daily model. The plant has a potential production of 48,000 vehicles.

\section{Irizar}

It is a cooperative that has manufactured buses since 1928 (40\% of its world production). A company with a substantial investment in R\&D is an example of an OEM bus chassis manufacturer. In 2016, they sold the first three electric buses. They have specialized in electric buses which they export with success. 
We can summarize that Spanish automotive plants have a relevant production capacity. But what do investments in R\&D of these agents record? CDTI (National Centre for Technology Development) has provided us with investment in CDTI projects from OEMs and component manufacturers. Given the selection and monitoring of projects by this body it is a very reliable reference. Table 3 presents the R\&D investment into automotive industries (OEMs) by communities over the period 2006-2014. This chart shows the clear leadership of the clusters of Castilla León, Catalonia, and Madrid. This investment corresponds to Renault, Nissan, and Seat and is consistent with the information provided by these firms and reflected in the preceding paragraphs.

Table 3. Assigned Budget for R\&D projects of automotive production plants (mill. Euros, 2006-2015, CDTI, 2015).

\begin{tabular}{|l|r|}
\hline Region & \multicolumn{1}{|l|}{ Total } \\
\hline Castilla Leon & 51,79 \\
\hline Cataluña & 25,69 \\
\hline Madrid & 18,49 \\
\hline Galicia & 4,18 \\
\hline Resto de CCAA & 4,09 \\
\hline Com. Valenciana & 4 \\
\hline Navarra & 0,49 \\
\hline Total & 108,73 \\
\hline
\end{tabular}

\section{Component manufacturers}

The Spanish Components Industry is another of the sector's key competitiveness agents, being the 4th largest component producer in Europe. In 2016, components were produced amounting to 34,000 million euros, surpassing the historical maximum of 33,000 million euros of 2007 , with $60.3 \%$ being exported, $26.3 \%$ to the domestic OEMs market and $13.4 \%$ to the national aftermarket.

On the other hand, components worth $22,950.76$ million euros had to be imported, of which $68.8 \%$ was allocated to domestic OEMs, $23.0 \%$ as input for component manufacturers and $7.4 \%$ to the domestic aftermarket. The level of investment in turnover was $6.1 \%$ and in the R\&D it was $3 \%$. The industry had employed 215,000 workers in 2016, a figure that before the crisis (2006) reached almost 250,000 . These figures give an idea of the degree of internationalization of the sector, its impact on the national economy, the level of investment in capital and R\&D required and, in short, the added value generated (SERNAUTO estimates 3.2\% of the Gross National Value Added and $58 \%$ of the GVA of the automotive industry). The contribution of the auxiliary sector to export is more than $90 \%$ of the volume produced (SERNAUTO, 2018).

The sector is made up of some 1, 200 companies that manufacture Automotive Equipment and Components, installed throughout the country, belonging to various multinational business groups as well as SMEs. Only 38 companies (3.17\%) are of considerable size and, of these, only 5 are Spanish (Gestamp, Grupo Antolín, Cie Automotive, Ficosa y Mondragón Automoción), with an ample size and internationalization, since the rest are subsidiaries of foreign multinationals in the sector. These have been attracted by the activity of OEMs as pointed out by academic literature (Sturgeon et al., 2004, 2008). A recent thesis defended in the UPV pointed out that the strategy of implementation of OEMs was the only determining element of the localization strategy of TIER1 and TIER2 (Ferrari, 2014).

To determine the distribution of companies in this sub-sector by size according to the various clusters, we have analyzed the population by Autonomous Community in the SABI. The data are shown in Table 4 . We have selected the data for companies with more than ten employees, so the sum is different from that presented in the table above. Both adjustments have been made in both cases to include some of the matrix companies that were included in the SABI in different NACEs (components 29.3). 
Table 4: Analysis of the firm's geographic distribution population and size of the Automotive Components sector (source SABI, 2017).

\begin{tabular}{|l|l|l|l|l|l|}
\hline Spain & $<50$ & $\mathbf{5 0 - 1 0 0}$ & $\mathbf{1 0 0 - 5 0 0}$ & $>\mathbf{5 0 0}$ & Total \\
\hline Andalucía & 22 & 5 & 4 & 2 & 33 \\
\hline Aragón & 30 & 13 & 17 & 2 & 62 \\
\hline Cantabria & 2 & 3 & 1 & 0 & 6 \\
\hline Castilla y León & 17 & 5 & 20 & 4 & 48 \\
\hline Cataluña & 115 & 26 & 59 & 10 & 210 \\
\hline $\begin{array}{l}\text { Comunidad } \\
\text { Valenciana }\end{array}$ & 20 & 3 & 25 & 1 & 49 \\
\hline Galicia & 24 & 6 & 13 & 3 & 46 \\
\hline Madrid & 38 & 7 & 7 & 5 & 57 \\
\hline Murcia & 5 & 0 & 0 & 0 & 5 \\
\hline Navarra & 25 & 14 & 22 & 6 & 67 \\
\hline País Vasco & 43 & 16 & 20 & 5 & 84 \\
\hline Todas & 341 & 98 & 188 & 38 & 665 \\
\hline
\end{tabular}

In general, OEM purchases are based on global platforms; competitiveness and quality criteria, but there are also certain trends to establish closer relationships with suppliers (Cusumano and Takeishi, 1991; Pilkington and Pedraza, 2014). Therefore, even if decisions are made at OEM sourcing headquarters, local OEM assembly facilities in clusters can have some influence on these decisions. This situation has also influenced the dynamics of growth and internationalization of some Spanish component companies that are occupying leadership roles at a global level. We can point out that the presence of component companies of a larger size determines leadership in the largest cluster of this agent for its ability to develop R+D activities and internationalize its operation having customers, not only outside the cluster but outside the country. In this sense, the components sector has larger companies mainly in the following industries.

A survey of 55 suppliers conducted by the authors ranked Spanish OEMs as follows (see Table 5) according to their collaborative relations with suppliers (according to the responsive value chain concept).

Table 5: Classification of Spanish based OEMs according to their cooperative level with national suppliers (survey by authors)

\begin{tabular}{|l|c|}
\hline OEM & $\begin{array}{c}\text { Cooperative level: } \\
\text { 5 maximum }\end{array}$ \\
\hline Audi & 4.13 \\
\hline Mercedes & 3.95 \\
\hline GM & 3.76 \\
\hline PSA & 3.6 \\
\hline Nissan & 3.51 \\
\hline Iveco & 3.39 \\
\hline Renault & 4.17 \\
\hline Ford & 3.06 \\
\hline VW & 3.03 \\
\hline Seat & 3.0 \\
\hline
\end{tabular}

Just as we have done with OEM assemblers, Table 6 shows the R\&D investment of component manufacturers in the period 2006-2014 disaggregated by the Autonomous Community. A clear leadership of the Basque Country and Catalonia is noted here, closely followed by Navarre, Castilla-Leon, and Madrid. 
Table 6: Assigned Budget to R\&D projects of automotive components production plants (mill. Euros, 2006-2015, National development Office for Technology or CDTI, 2015).

\begin{tabular}{|l|c|}
\hline Region & Total \\
\hline Pais Vasco & 112.31 \\
\hline Cataluña & 106.73 \\
\hline Navarra & 62.66 \\
\hline Castilla y León & 54.15 \\
\hline Madrid & 43.13 \\
\hline Galicia & 27.04 \\
\hline Com. Valenciana & 23.83 \\
\hline Aragon & 9.74 \\
\hline Resto CCAA & 101.76 \\
\hline Total & 541.35 \\
\hline
\end{tabular}

Clusters Industry associations.

Currently, there are 11 automotive clusters, some of them in the association ACREA, and with different levels of success and growth, depending on the local circumstances of each case (Beldarrain \& Clemente, 2010). In Figure 2 we present the geographical location of the automotive clusters in Spain.

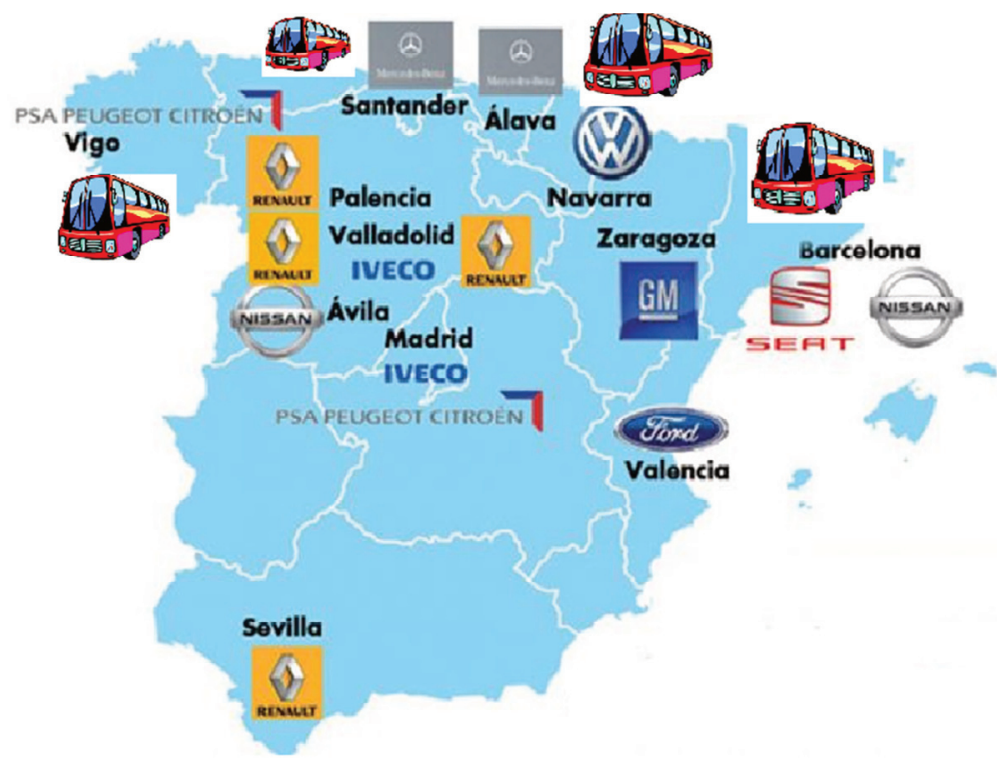

Figure 2: Geographical location of automotive clusters in Spain (Source authors, based on ANFAC and ASCABUS).

In 1993, the Basque Country Automotive Cluster (ACICAE) was created. It has about 151 members. The OEMs active in this geographical area are Daimler Benz Vitoria and Irizar, with R\&D and the collaboration of other centres such as CEIT, IK4, and Tecnalia. Among the most crucial TIER 1 companies, Tenneco, ZF, Gestamp, etc. are worth mentioning.

The second one created in Spain was the Galician Automotive Business Cluster (CEAGA) in 1997. One of the most active in the country, it currently has about 103 members. The active OEM is PSA-Citroën, with a well-known Galician Automobile Technology Centre (CTAG) and the technical centre of the PSA group located in Vigo. Among the most critical TIER 1 companies, ACS, Autoneum Spain, S. A., Benteler, Borg Warner Emissions, Faurecia, Coperma, Denso, Rubi, Gestamp, GKN, Antolín, Inergy, Plasto, etc. should be highlighted. 
In 2001 the Castilla y León Automotive Forum (FACYL) was created at the request of OEMs such as Renault, Nissan, and Iveco. It currently has about 30 members. Its projects are based on the collaboration of the CIDAUT Foundation and the University of Valladolid.

The Valencia Association of Automotive Auxiliary Industry (AVIA) was created in 2003 under the auspices of the Generalitat Valenciana and the impulse of the region's OEM, Ford España, S. A. This cluster currently has about 69 members, although with low activity. Among the most important TIER 1 companies, we should highlight Faurecia, Grupo Antolín, Autoliv-BKI, Ochoa, COPO, TMD, Tenneco, etc. Faurecia has recently inaugurated an R\&D centre in Paterna with an investment of nearly €3 million and 330 employees.

In 2005, the Cantabria Regional Automotive Initiatives Group (GIRA) was formalized, a small cluster with some 30 partners and generated under the auspices of an OEM such as Mercedes. Today it represents $30 \%$ of the regional GNP.

The NAVARRA Automotive Cluster was created in 2007 and currently has 120-130 companies. The active OEM is Volkswagen, with the R\&D capabilities of CITEAN and the Universities of Navarra and Navarra Public University. The most essential TIER 1 companies that belong to it are SKF, FrenosIruña, KWD-Schnellecke, KYB, GAN Technologies, etc.

The Automotive Cluster of the Madrid Region (MCA) was also created in 2007. It currently has 26 partners, of which the PSA Peugeot and Citroën Group companies stand out as the leading OEMs, as well as IVECO, heir to the former ENASA. The most important TIER 1 companies in the cluster are Robert Bosch, Valeo, Faurecia, Eaton, April, TRW, etc.

The Aragon Automotive Cluster was created in 2008 with a series of companies linked to General Motors. It has 28 companies, including OEMs such as TATA and ZYTEL .

The Innovative Business Association of the Automotive Sector of Jaen (AEI Jaen) was born under the umbrella of OEM Suzuki in 2008 (today extinct).

Finally, in April 2013, the Catalan Automotive Cluster was born. It has about 251 companies and is the largest in Spain. It was created under the auspices of OEM SEAT and NISSAN and TIER 1 FICOSA, DOGA and GESTAMP. The participating OEMs also include the VW-AUDI group. Different technology centres belonging to the OEMs, as well as other centres such as IDIADA, participate in R\&D support (Alaez et al., 2018).

The strength of some clusters is determined, for example, by the existence of links between agents before their constitution, as in Castilla León, Galicia and the Basque Country (Beldarrain \& Clemente, (2010). One aspect common to most associations is their economic dependence on public support for their subsistence, which shows a significant weakness.

All of these offer R\&D services in their respective portfolios of activities, but no statistics or data on the R\&D projects they lead are published, but are limited to the description of the R\&D activities of the associated technological centres. In most cases, R\&D in cluster partner universities is not related to their technical interests.

The activities most valued by the partners are as follows: Advice to companies on the management of public aid; training in Lean manufacturing; Purchasing Centre; Internationalisation; Cooperation networks; Management training; R\&D in electric vehicles; R \& D work groups; Groups for the improvement of the quality of the services provided by the company.

\section{$\underline{\text { Universities }}$}

The analysis of the various clusters shows a low participation of universities in these clusters, even in areas of training as evidenced by the closure of Ford's university school in 2013.

The Spanish automotive industry is mainly based on the manufacture and assembly of vehicles. The R\&D link is the only one missing to complete the value chain. The Spanish university has not been concerned with the training of engineers specialized in the automotive sector; this has also been enhanced by the fact that many OEM companies have their decision centres, and therefore development centres, connected to other countries, further distancing the university from companies (Albors-Garrigós, Collado \& Dolz, 2017).

In some cases, their contribution has been important in logistics and production R\&D and training as the case of Valencia `Polytechnic University shows. 
R\&D Centres, Technological Institutes.

In principle, technology centres play an intermediate role between universities and industry (Albors-Garrigós \& Rincon Diazl., 2014). Given the situation described above, certain AAAs have set up technical centres, with the aim of leading R\&DI in the automotive sector in their geographical area of influence. Although most rely on public funds and subsidies, some of them, such as CTAG, founded in 2002 (300 employees), stand out for generating funds from their resources. An essential role of these centres is their accreditation as vehicle and component homologation laboratories (INTA and IDIADA) which give them some economic sustainability. The rest, dependent on services to OEM or TIER 1,2 and 3 will depend on their competitiveness.

The fact that some OEMs have their R\&D technology centres, as has already been pointed out, raises the question of whether there will be a spillover of knowledge in the cluster itself as pointed out by academic literature (Audretsch \& Feldman, 2004) in the face of the trend of appropriateness.

The challenge is the empowerment of these centres and their collaboration with the component industry whose R\&D capacity is limited by their size.

\section{Unions.}

The role that trade unions play in the sustainability of the automotive industry in general, OEMs and Auxiliary Industry, can be considered of great importance through their industrial observatories and their participation in the improvement and stability of labour relations.

For this reason, in those Autonomous Regions where there is a strong union presence due to the presence of OEMs and large companies TIER 1 and TIER 2, their influence will be more significant.

Local Government and Administration.

Public administrations play a fundamental role in promoting R\&D through public-private collaboration. The central government has played a reactive role in the reactions and suggestions of the industry agents and supporting the R\&D efforts of the sector.

Other local and regional public administrations have played a lesser role by supporting the cluster organizations, the innovative developments, the training programmes, etc. The European Union has also played a support function by organizing and promoting clustering activities or through the financing of R\&D through the European Commission research programmes (Albors-Garrigoa \& Rincon Diazl., 2017).

\section{Discussion and Analysis}

The dynamism of the various actors involved in clusters has been analyzed, assigning values to the different variables that make up the dynamic elements pointed out in Fgure 1. Strength and openness have been standardized according to the averages obtained between the various clusters, with performance as shown in Table 1. Table 7 below presents the values obtained in each cluster by the dynamism of the different agents. It can be noted that cluster leadership can be attributed primarily to OEMs, component manufacturers and the interaction between them.

\section{Measurement and appraisal of the model}

The Partial Least Squares (PLS) method was used for this analysis. The data do not have to meet the requirement of normality. Indeed, this is one of the motivations for using PLS Path Modelling (Henseler, Ringle, \& Sinkovics, 2009, p. 277-319). PLS can appraise both the consistency and soundness of the instrument. According to Hair, Hult, Ringle \& Sarstedt (2013), the sample size should be ten times the most significant number of formative indicators used to measure a single construct or ten times the most substantial part of a structural path directed at a particular construct in the structural model. Thus, the more significant number of structural paths directed to a specific construct is 4 , and therefore the minimum sample size required would be 40 samples. In this case, the sample size used in the model (99) is much higher than needed to run the PLS with confidence. However, the subsample sizes (Regions) are not acceptable according to the cases per dependent variable. Additionally, no missing data have been reported on the completed surveys.

As suggested by Chin (2001), we used separate item loadings to appraise individual item reliability. Values with loadings higher than 0.7 are considered acceptable, meaning the subject explained about $50 \%$ of the variance in a particular element. This precaution ensures that items in the measurement construct measure the same model. Composite reliability evaluated the internal consistency of each construct. The minimum acceptable composite reliability level is 0.7 for each item loading (Nunnally \& Bernstein, 1994). Finally, the discriminant validity was checked using the average variance extracted (AVE) and the squared inter-corre- 
lations. The AVE values should be higher than 0.5 , and the crossed correlations among the latent variables should not exceed the square root of the AVE values to justify the discriminant validity (Chin, 2001). The AVE is reported in Table 7. The results shown demonstrate that the measurement models are assessed with confidence. When using PLS, leading statisticians communicate, the correlation matrix (with the Square root of AVE on diagonal) is used to check for discriminant validity of the measures.

Table 7: Reliability measurements

\begin{tabular}{|c|c|c|c|c|}
\hline & AVE & $\begin{array}{c}\text { Composite } \\
\text { Reliability }\end{array}$ & R Square & $\begin{array}{c}\text { Cronbach's } \\
\text { Alfa }\end{array}$ \\
\hline CLUST OPENN & 0.882 & 0.967 & & 0.955 \\
\hline CLUSTERSTR & 0.831 & 0.952 & 0.739 & 0.933 \\
\hline PERFORMANCE & 0.612 & 0.824 & 0.759 & 0.786 \\
\hline UNCERTAINTY & 0.714 & 0.873 & 0.900 & 0.798 \\
\hline
\end{tabular}

Figure 3 shows the results of the structural model proposed for the sample. Observable questionnaire items are represented in rectangles and unobservable latent factors with circles. Partial regression coefficients, corresponding to endogenous variables, are indicated next to the arrows and the ratio of determination $\left(R^{2}\right)$ for the corresponding regressions is inside the circles.

The standardized betas or path coefficients indicate the strength of the causal associations between two latent variables. To test the significance of these relationships, we estimated regression coefficients between latent factors, their t-statistics, and p-values, using bootstrapping and blindfolding procedures with 5,000 samples (see Table 4 and Table 5). The Stone Geiser coefficients $\left(Q^{2}\right)$ are more significant than zero indicating that the model has a positive predictive relevance.

It can be observed that the experimental model indicates a more relevant role in the environment uncertainty factor than the proposal by Eisingerich et al. (2010). Cluster openness seems to affect uncertainty in 90,9 $\%$ and influences cluster performance through the uncertainty variable. On the other hand, Environment uncertainty affects cluster strength in $73.9 \%$. Its effects on cluster performance are $0.532 / 0,759(70.0 \%)$ while the influence of cluster strength is $0.278 / 0,759$ (30.0\%). In this case, Environment uncertainty plays an important role in the model.

Concerning the four variables considered for the Cluster Strength, both the Responsive Value Chain and the OEM Leadership have the most substantial effects while the Cluster Governance and the Union's coherence have lower results.

Cluster openness reflective variables have high loads except for new members who have a lower weight.

As regards the Environment uncertainty factors, the OEM de-investment threats have a lower impact while technology and environmental turbulence have a very high impact. Expert reports have outlined many necessary changes in the automotive .sector which will have an effect in its near future development. They predict a reduction in ownership in favour of vehicle sharing; more autonomous and connected vehicles will be running on the roads, actual conventional combustibles are questioned; the productivity ratios are being challenged by emerging producing countries and new technology paradigms such as industry 4.0. A new concept of remanufacturing to facilitate a car shorter life has developed as well. These threats pose hurdles that can only be surmounted by more open networks and collaborative schemes and this explains the critical role shown by uncertainty in the research model.

Finally, the cluster performance variables have in general a lower impact since most cluster regions have a high weight of their automotive industry and therefore the variance is moderate. 


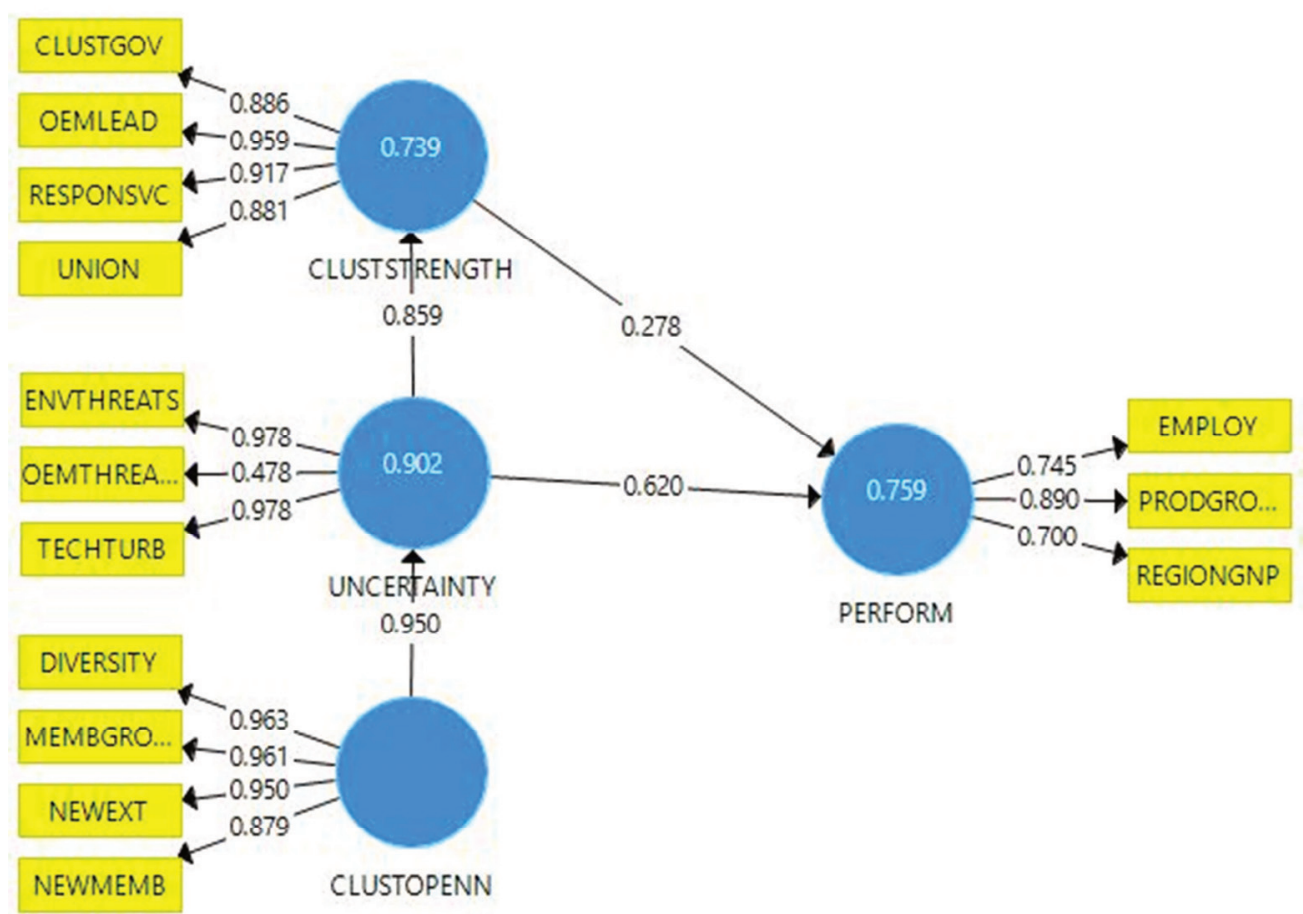

Figure 3: Estimated structural equations model using the sample.

Table 8: Matrix of correlation between latent variables.

\begin{tabular}{|c|c|c|c|c|}
\hline & $\begin{array}{c}\text { CLUST } \\
\text { OPENN }\end{array}$ & CLUSTERSTR & PERFORMANCE & UNCERTAINTY \\
\hline CLUST OPENN & $\mathbf{0 . 9 3 9}$ & & & \\
\hline CLUSTERSTR & 0.904 & $\mathbf{0 . 9 1 2}$ & & \\
\hline PERFORMANCE & 0.833 & 0.811 & $\mathbf{0 . 8 8 2}$ & \\
\hline UNCERTAINTY & 0.940 & 0.859 & 0.859 & $\mathbf{0 . 9 4 5}$ \\
\hline
\end{tabular}

Note: Square root of AVE on diagonals in bold.

Table 9: Direct effects, explained variances and Stone GeiserQ ${ }^{2}$ test for the endogenous variables.

\begin{tabular}{|l|c|c|c|}
\hline Effects on endogenous variables & $\begin{array}{c}\text { Direct effect } \\
\text { (t-value) }\end{array}$ & $\begin{array}{c}\text { Variance } \\
\text { explained }\end{array}$ & $\begin{array}{c}\text { Path Coeff. } \\
\text { Diff. } \\
\text { p-Value }\end{array}$ \\
\hline EFFECTS ON PERFORM & $\mathrm{R} 2=0.759$ & $\mathrm{Q} 2=0.328$ & \\
\hline CLUSTSTRENGTH > > > PERFORM & $6.452^{\star *}$ & 0.2254 & $<0.000$ \\
\hline UNCERTAINTY>> > PERFORM & $10.670^{\star *}$ & 0.53258 & $<0.000$ \\
\hline EFFECTS ON UNCERTAINTY & $\mathrm{R} 2=0.900$ & $\mathrm{Q} 2=0.586$ & \\
\hline CLUSTOPEN > > > UNCERTAINTY & $86.598^{\star *}$ & 0.902 & $<0.000$ \\
\hline EFFECTS ON CLUSTRENGTH & $\mathrm{R} 2=0.739$ & $\mathrm{Q} 2=0.560$ & \\
\hline UNCERTAINTY>>> CLUSTRENGTH & 34.490 & 0.739 & $<0.000$ \\
\hline
\end{tabular}

*** Significant at $p<0.001, * *$ Significant at $p<0.01,{ }^{\star}$ Significant at $p<0.1$

Table 10 shows the average value of the various factors considered in the research. As mentioned the size of the sample did not allow us to analyse the model region by region. However, the strongest clusters show higher figures of cluster strength, openness and a higher resilience towards uncertainty threats. 
Table 10: Influence of diverse agents and factors in the Spanish automotive clusters

(1 minimum, five maximum, mean values).

\begin{tabular}{|c|c|c|c|c|c|c|c|c|c|c|c|c|c|c|}
\hline & \multicolumn{4}{|c|}{ Cluster Strength } & \multicolumn{4}{|c|}{ Cluster Opeqness } & \multicolumn{3}{|c|}{ Threats } & \multicolumn{3}{|c|}{ Performance } \\
\hline EG & 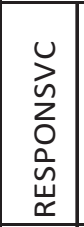 & 虽 & $\begin{array}{l}z \\
\text { o } \\
\text { z }\end{array}$ & 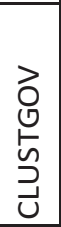 & 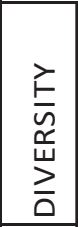 & $\sum_{\sum}^{\infty}$ & 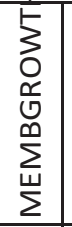 & 点 & 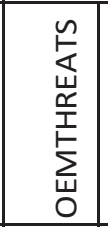 & 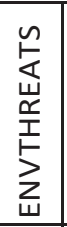 & 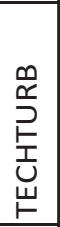 & 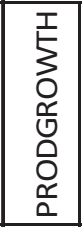 & $\begin{array}{l}\text { ò } \\
\sum_{\text {ù }}^{a}\end{array}$ & 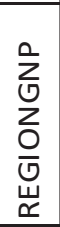 \\
\hline Cata & 4.3 & 4.5 & 3.7 & 3.5 & 5.0 & 4.3 & 4.3 & 4.3 & 2.3 & 3.7 & 4.0 & 4.0 & 4.3 & 3.7 \\
\hline Gali & 3.5 & 3.3 & 3.5 & 4.5 & 4.0 & 2.5 & 4.0 & 4.0 & 2.3 & 3.3 & 3.0 & 3.0 & 4.0 & 3.3 \\
\hline Arag & 3.3 & 3.0 & 3.0 & 4.3 & 3.0 & 3.0 & 3.0 & 3.0 & 3.8 & 2.5 & 3.0 & 3.0 & 3.0 & 3.0 \\
\hline Castilla & 4.3 & 4.3 & 3.3 & 4.5 & 4.3 & 5.0 & 4.5 & 4.3 & 1.3 & 3.7 & 5.0 & 4.0 & 4.5 & 4.5 \\
\hline Nav & 3.5 & 2.7 & 2.0 & 3.7 & 3.0 & 5.0 & 3.7 & 3.0 & 1.8 & 3.7 & 4.0 & 4.0 & 3.7 & 3.7 \\
\hline País & 3.3 & 2.5 & 2.3 & 3.3 & 3.5 & 4.3 & 3.3 & & 2.3 & 3.3 & 3.0 & 3.0 & 3.3 & 3.5 \\
\hline Valencia & 1.8 & 2.0 & 2.5 & 2.0 & 2.5 & 2.5 & 2.0 & 2.3 & 4.0 & 2.3 & 2.0 & 2.0 & 2.3 & 2.7 \\
\hline Madrid & 1.3 & 1.5 & 1.8 & 2.0 & 1.8 & 2.0 & 2.0 & 2.5 & 1.8 & 2.5 & 2.0 & 2.0 & 2.3 & 2.5 \\
\hline Cantabria & 1.8 & 0.3 & 1.0 & 1.8 & 1.0 & 2.0 & 2.0 & 1.8 & 1.3 & 2.0 & 2.0 & 2.0 & 1.0 & 2.0 \\
\hline Andalucia & 1.3 & 0.8 & 1.0 & 1.0 & 1.0 & 1.8 & 2.0 & 1.0 & 1.8 & 2.0 & 2.0 & 2.0 & 1.3 & 2.3 \\
\hline
\end{tabular}

Conslusion

It can be deduced that, by confirming what academic literature points out, automotive clusters should be analyzed from the perspective of the global value chain in this sector and the technology predictions by experts. Therefore, and given the above analysis, it is worth highlighting, in comparison with other types of industrial clusters, the critical and fundamental role of car manufacturers and the degree to which they carry out value-added activities (R\&D, design) in the cluster. This role explains the dynamism of clusters such as Cataluña, Galicia or Castilla León. This dynamism has also led to the emergence of large component companies, which in turn have grown and become internationalized. On the other hand, the policies of the OEM companies and their involvement and commitment to the region (the cluster) are fundamental, and this can explain the case of Galicia or Madrid and the role that some Spanish production managers played in this process.

Component companies are a vital link in complementing OEMs in their development. On the one hand, as a large part of the academic literature has pointed out, the strategies of multinational companies of Tier 1 and 2 components are attracted by the outsourcing strategies of OEM companies and the new trends in the sector encourage greater collaboration between OEM and suppliers. On the other hand, the opportunities generated in the cluster can be taken advantage of by entrepreneurs to grow and internationalize, and that is the case of the companies already mentioned. Here, the context and industrial culture of the region is essential, hence the dynamics of Cataluña and the Pais Vasco. In case of Madrid, it should be remembered that ENASA (Empresa Nacional de Autocamiones) was founded in 1946 and Barreiros Diésel in 1954 (García-Ruiz \& Santos-Redondo, 2002). In this sense, it is worth highlighting the success story of Galicia and Castilla León, where this traditional industry did not exist.

The component industry will play a critical role in new car future to facilitate the radical technology changes to come. Electrified, autonomous, shared, connected and yearly updated.

Concerning industrial associations of automotive clusters, they are a relatively different figure in the cluster literature, they play an important role but, from the authors' point of view, primarily when there was already a seed and a previous collaboration between the agents of the cluster. Perhaps their fundamental task is that of formation, at all levels, in which they play a significant role.

$R \& D$ centres are relevant as knowledge generators and transfer agents, but there are few examples of success. It is problematic,and sustainability approach is common to that of technology centres (Albors et al., 2014). Cluster associations can be an essential support for the cluster sustainability, such as CEAGA.

Universities, with some exceptions already mentioned, are far removed from the automotive sector and do not seem to respond to the demands of it. 
Trade unions, and this is also a peculiarity of this sector, have a specific role to play in improving industrial relations in the clusters, but their influence seems limited to large OEMs and Tier 1 companies. Examples of human resource conflicts (EREs, closures) in smaller businesses seem to illustrate this conclusion.

In some cases, they have limited themselves to subsidizing industry and OEM investment plans, among others; they have supported clusters and the component industry even by launching regional strategies for the sector. In any case, budget cuts have considerably limited its scope. Recently, ANFAC has requested support from the national government for a new strategic plan for automotive manufacturers.

Finally, the role of central and regional administration seems to differ. The national industry associations such as SERNAUTO and ANFAC have shown a strong cohesiveness. As a consequence, the central government has acted more reactively. First, it is by limiting them to accept the sector's proposals regarding support for investments in production infrastructure and R\&D and, second, by implementing incentive plans for the purchase of new vehicles. The latter has been useful in articulating a minimum demand of the national market that would make the arrangements for outsourcing of the OEMs to Spain viable. The work of the CDTI with a particular tradition must be highlighted. The attitude of the involved Regions' administrations has been different. A critical role of public administration will be to administer and support new regulations in a flexible way.

The paper has relevant implications for public policies in emerging countries. Among others: promoting and supporting the automotive industry requires the specific support of the automotive components firms, supporting networking and collaboration among public and private agents with the focus on helping the establishment of higher value-added activities in the country's automotive value chain and, finally, supporting the cooperation of R\&D organizations with the industry. In case of Spain, the EU clustering support has been useful diverging from what has been pointed out in other European emerging economies (Welfens, 2014, p.78). In general, the development of, at least, a minimum size of local components industry is essential for the cluster development and this questions some propositions of academic literature (Welfens, 2014, p. 113).

The limitations of this paper lie in the extension of the sector and the need of more resources to deepen these studies, given the relevance and future of the automotive industry which will be the object of future research.

\section{Acknowledgments}

This research study has been supported by various national organizations (MINETUR; CDTI; ANFAC, SERNAUTI) as well as regions such as clusters associations around Spain.

\section{REFERENCES}

[1] Akpinar, M., \& Vincze, Z. (2016). The dynamics of coopetition: A stakeholder view of the German automotive industry.Industrial Marketing Management, 57, 53-63. DOI: 10.1016/j.indmarman.2016.05.006

[2] Alaez Aller, R.; Longas Garcia, J.C.; Ullibarri Arcer, M.; Bilbao Ubillos, J.; Camino Beldarrain, V.; \& Clemente, G. (2010). "Los clusters de automoción en la Unión Europea”. Revista Economía Industrial. 376, 97-104

[3] Albors-Garrigos, J., Collado, A., \& Dolz, F. (2017). Factores de éxito de la clusterización de la industria del automóvil en España. El rol de los agentes en el clúster. Economía industrial, 403, 125-134.

[4] Albors-Garrigos, J.; Rincon-Diaz, C.; \&Igartua-Lopez. J. (20149. Research technology organizations as leaders of R\&D collaboration with SMEs: role, barriers, and facilitators. Technology Analysis \& Strategic Management, 26, 37-53. DOI: 10.1080/09537325.2013.850159

[5] ANFAC (Asociacion Nacional de Fabricantes de Automoviles y Camiones; National Association of Automobiles and Trucks Manufacturers), Annual Reports, 2015-2018. Madrid.

[6] ASCABUS (2018), National Association of Bus Chassis manufacturers, Madrid.

[7] Audretsch, D. B., \& Feldman, M. P. (2004). Knowledge spillovers and the geography of innovation. Handbook of regional and urban economics, 4, 2713-2739. DOI: 10.1016/S1574-0080(04)80018-X

[8] Banyuls, J.M. y Lorente Campos, R. (2010) La industria del automóvil en España: Globalización y gestión laboral. Revista de Economía Crítica, 9, 31-52.

[9] BCG. (2013). Estudio para el fortalecimiento y desarrollodel sector industrial en España. The Boston Consulting Group. Ministerio de Industria, Energía y Turismo. Madrid.

[10] Bhaskaran, E. (2014). The productivity analysis of chennai automotive industry cluster. Journal of The Institution of Engineers (India): Series C, 95(3), 239-249. DOI: 10.1007/s40032-014-0120-6 
[11] Bierau, F., Perlo, P., Müller, B., Gomez, A. A., Coosemans, T., \& Meyer, G. (2016). Opportunities for European SMEs in global electric vehicle supply chains in Europe and beyond. In Advanced Microsystems for Automotive Applications 2015 (pp. 223-235). Springer, Cham.

[12] Brenner, T. (2017). Identification of Clusters-An Actor-based Approach (No. 2017-02). Philipps University Marburg, Department of Geography.

[13] Cabelkova, I., Normann, R., \& Pinheiro, R. (2017). The Role of Higher Education Institutions in Fostering Industry Clusters in Peripheral Regions: Strategies, Actors and Outcomes. Higher Education Policy, 30(4), 481-498. DOI: 10.1057/s41307-017-0059-3

[14] Catalan, J. (2017). The Life-Cycle of the Barcelona Automobile-Industry Cluster, 1889-2015. Revista de Historia Industrial, 2017,66(26), 77-125.

[15] Chin, W. W. (2001). PLS-Graph user's guide. CT Bauer College of Business, University of Houston, USA.

[16] Cusumano, M. A., \&Takeishi, A. (1991). Supplier relations and management: a survey of Japanese, Japanese-transplant, and US auto plants. Strategic Management Journal, 12(8), 563-588. DOI: 10.1002/smj.4250120802

[17] Dibben, P., Meira, J., Linhares, C., Bruce, R., \& Wood, G. (2016). Vanishing value chains, industrial districts and HRM in the Brazilian automotive industry. The International Journal of Human Resource Management, 1-18. DOI: 10.1080/09585192.2016.1233446

[18] Dibben, P., Wood, G. T., Linhares, C., \& Meira, J. (2016). Industrial Clusters, Value Chains And HRM In The Brazilian Automotive Industry. In Academy of Management Proceedings(Vol. 2016, No. 1, p. 12333). Briarcliff Manor, NY 10510: Academy of Management.

[19] Dyer, J. H., \& Chu, W. (2003). The role of trustworthiness in reducing transaction costs and improving performance: Empirical evidence from the United States, Japan, and Korea. Organization science, 14(1), 57-68. DOI: 10.12691/jfe-2-5-9

[20] Eisingerich, A. B., Bell, S. J., \& Tracey, P. (2010). How can clusters sustain performance? The role of network strength, network openness, and environmental uncertainty. Research policy, 39(2), 239-253. 10.1016/j.respol.2009.12.007

[21] Evren, Y., \& Sakarya, A. (2017). Resilience, Rivet Effect and the Changing Geography of Production Chains in the Turkish Automotive Industry. Journal of Planning, 28(1),12-21. DOI: 10.14744/planlama.2017.36035

[22] Ferrari-Solis, A. (2014), Determinación de los factores críticos y moderadores de los procesos de localización industrial en el sector del automóvil y su impacto en la geografía mundial de la producción de vehículos. Doctoral Thesis, Univ. Pol. Valencia, July. Valencia.

[23] Forster, B. (2015). Technology foresight for sustainable production in the German automotive supplier industry. Technological Forecasting and Social Change, 92, 237-248.

[24] García-Ruiz, M.\& Santos-Redondo, J.L. (2002). iEs un motor español! Historia empresarial de Barreiros, Madrid: Editorial Síntesis

[25] Gereffi, G., \& Fernandez-Stark, K. (2016). Global value chain analysis: a primer.The Duke Center on Globalization, Governance \& Competitiveness (Duke CGGC), Durham, NC.

[26] Gereffi, G., Humphrey, J., \& Sturgeon, T. (2005). The governance of global value chains.Review of the international political economy, 12(1), 78-104.

[27] Gunasekaran, A., Lai, K. H., \&Cheng, T. E. (2008). Responsive supply chain: a competitive strategy in a networked economy. Omega, 36(4), 549-564.

[28] Hair Jr, J. F., Hult, G. T. M., Ringle, C., \& Sarstedt, M. (2016). A primer on partial least squares structural equation modeling (PLS-SEM). Sage Publications.

[29] Hassink, R., Plum, O., \& Rickmers, A. (2014). On the implications of knowledge bases for regional innovation policies in Germany. Quaestiones Geographicae, 33(4), 7-16.

[30] Henseler, J., Ringle, C. M., \& Sinkovics, R. R. (2009). The use of partial least squares path modeling in international marketing. In New challenges to international marketing (pp. 277-319). Emerald Group Publishing Limited.

[31] Laseter, T. M., \& Ramdas, K. (2002). Product types and supplier roles in product development: an exploratory analysis. IEEE Transactions on Engineering Management, 49(2), 107-118.

[32] Lau, H. C., \& Lee, W. B. (2000). On a responsive supply chain information system.International Journal of Physical Distribution \& Logistics Management, 30(7/8), 598-610.

[33] Laux, J. M. (1992).The European automobile industry(p. 13). New York: Twayne.

[34] Morosini, P. (2004) "Industrial clusters, knowledge integration, and performance." WorldDevelopment 32(2): 305-326.

[35] Nedelcu, A. C., \& Buşu, C. (2015). Clusters performance in the Romanian Automotive Industry. In Proceedings of the International Management Conference (Vol. 9, No. 1, pp. 645-654). Faculty of Management, Academy of Economic Studies, Bucharest, Romania.

[36] Nunnally, J. C., \& Bernstein, I. H. (1994). Psychometric Theory (McGraw-Hill Series in Psychology) (Vol. 3). New York: McGraw-Hill. 
[37] Nyaga, G. N., Lynch, D. F., Marshall, D., \& Ambrose, E. (2013). Power asymmetry, adaptation and collaboration in dyadic relationships involving a powerful partner. Journal of Supply Chain Management, $49(3), 42-65$.

[38] Oh, J., \& Rhee, S. K. (2010). Influences of supplier capabilities and collaboration in new car development on competitive advantage of carmakers.Management Decision,48(5), 756-774.

[39] Pavlinek, P. (2015). The impact of the 2008-2009 crisis on the automotive industry: global trends and firm-level effects in Central Europe.European Urban and Regional Studies, 22(1), 20-40.

[40] Perez, M. P., \& Sanchez, A. M. (2002). Lean production and technology networks in the Spanish automotive supplier industry. MIR: Management International Review, 261-277.

[41] Pilkington, A., \&Pedraza, I. (2014). Innovation during the supplier selection process: A novel multi-stage process case. In Management of Innovation and Technology (ICMIT), 2014 IEEE International Conference onTechnology (pp. 262-267).IEEE.

[42] Plum, O., \&Hassink, R. (2013).Analysing the knowledge base configuration that drives southwest Saxony's automotive firms.European Urban and Regional Studies, 20(2), 206-226.

[43] Porter, M. E. (2000) Location, Competition, and Economic Development: Local Clusters in a Global Economy. Economic Development Quarterly, 14(1), pp. 15-34.

[44] Rutherford, T., \& Holmes, J. (2008). 'The flea on the tail of the dog': power in global production networks and the restructuring of Canadian automotive clusters. Journal of Economic Geography,8(4), 519-544.

[45] Rutherford, T., \& Holmes. J. (2007) "We Simply Have to Do that Stuff for our Survival": Labour, Firm Innovation and Cluster Governance in the Canadian Automotive Parts Industry." Antipode 39(1): 194-221.

[46] Rutherford, T., \& Holmes. J. (2008) "Engineering networks: university-industry networks in southern Ontario automotive industry clusters." Cambridge Journal of Regions, Economy, and Society, 1(2): 247264.

[47] Schulze, A., Paul MacDuffie, J., \& Schulze, A., Paul MacDuffie, J., \&Täube, F. A. (2015). Introduction: knowledge generation and innovation diffusion in the global automotive industry-change and stability during turbulent times.Industrial and corporate change, 24(3), 603-611.

[48] SERNAUTO, Annual Reports 2015-2018

[49] Spencer, G. M., Vinodrai, T., Gertler, M. S., \& Wolfe, D. A. (2010). Do clusters make a difference? Defining and assessing their economic performance. Regional studies, 44(6), 697-715.

[50] Stone, M. (1974). Cross-validation and multinomial prediction. Biometrika, 61(3), 509-515.

[51] Sturgeon, T. J., \& Van Biesebroeck, J. (2011). Global value chains in the automotive industry: an enhanced role for developing countries?. International Journal of Technological Learning, Innovation and Development, 4(1-3), 181-205.

[52] Sturgeon, T., \& Lester, R. K. (2004). The new global supply-base: New challenges for local suppliers in East Asia in Shahid Y., M. Altaf, A. and Nabeshima, K., eds.Global production networking and technological change in East Asia, The World Bank, Washington, D.C., pp. 35-88.

[53] Sturgeon, T., \& Van Biesebroeck, J. (2010). Effects of the crisis on the automotive industry in developing countries: a global value chain perspective.World Bank, Policy Research Paper, no. 5330. Washington DC.

[54] Sturgeon, T., Van Biesebroeck, J. \& Gereffi, G. (2008) "Value chains, networks, and clusters: reframing the global automotive industry." Journal of Economic Geography, 8(3): 297-321

[55] Sureephong, P., Chakpitak, N., Ouzrout, Y., Neubert, G., \& Bouras, A. (2007, December). Knowledge management system architecture for the industry cluster. In Industrial Engineering and Engineering Management, 2007 IEEE International Conference on (pp. 1970-1974). IEEE.

[56] Taura, N. D., \& Watkins, D. (2014). Counteracting innovative constraints: insights from four case studies of African knowledge-intensive metalworking and automotive clusters-'the Akimacs'. Entrepreneurship \& Regional Development, 26 (3-4), 313-336.

[57] Welfens, P. J. (Ed.). (2014). Clusters in Automotive and Information \& Communication Technology: Innovation, Multinationalization and Networking Dynamics. New York. Springer Science \& Business Media.

Received: 2018-02-01

Revisions requested: 2018-04-03

Revised: 2018-10-15 (2 revisions)

Accepted: 2018-12-12 


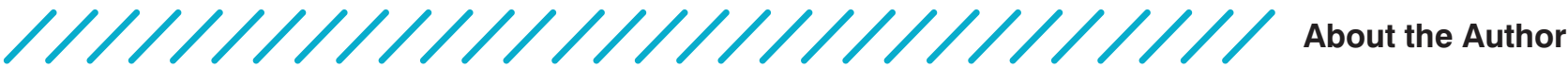

\author{
Jose Albors-Garrigos \\ Universitat Politécnicade Valencia \\ e-mail: jalbors@doe.upv.es
}

Emeritus professor at the Universitat Politécnica de Valencia (UPV) in Spain. Dr. Albors is an Industrial engineer from Univ.Pol. de Madrid where he was awarded a PhD degree and an MBA. With more than 25 years professional experience in engineering Dr. Albors joined the UPV in 1995 becoming Full professor in 2010. He has ample academic and research experience in the fields of Innovation and Technology Management as well as Knowledge Management where he has been consultant and researcher. He has published more than 80 articles in international journals and 150

papers in international conferences.

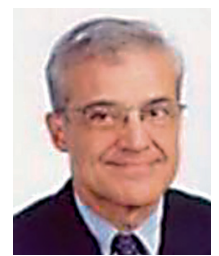

Antonio Collado

Ford Spain

e-mail: acollado@ford.com

PhD Estudent at the Universitat Politécnica de Valencia (UPV) in Spain. A. Collado is an industrial engineer from U. L. de Tarragona. He was awarded an MBA degree at the Anglia Ruskin University, Chelmsford campus in UK. Antonio has more than 40 years professional experience in engineering and quality systems management at the Ford

Motor Co. in Spain. He is now working on a research in the Spanish automotive industry in partial fulfillment of the requirements for the PhD Degree at the Universitat Politécnica de Valencia (UPV) in Spain.

APPENDIX 1: Abbreviations

ANFAC Spanish Association of Automotive and Truck Manufacturers

OEM Original Equipment Manufacturers

GVC Global Value Chains

GM General Motors

PSA Peugeot

CCAA Regional Autonomy Offices

IVECO Italian Truck Vehicles Corporation

VW Volkswagen

ASCABUS National Association of Bus Manufacturers

MINETUR Ministry of Industry \& Tourism

R\&D Research \& Development

SERNAUTO National Association of Components Manufacturers

GNP Gross National Product.

ERE Temporary Employment Suspension

CEAGA Galician Automotive Cluster

TIER, 1, 2, 3 OEM supplier of 1, 2 or 3d.order

CDTI National Development Office for Technology

NACE National Classification of Economic Activities

FACYL Castilla Leon Automotive Association

AVIA Valencia Automotive Industry Association

CIDAUT Castilla Leon Research \& Development Charity

CTAG Galician Technology Automotive Development Office

GNP gross national Product

ENASA National Truck Manufacture Corporation

ACREA Alliance of Regional Automotive Clusters

Detailed notes on automotive industry data have been deleted due to shortage of space. Refer to the author if you are interested. 